\title{
TINGKAT PENGETAHUAN DAN KEPATUHAN MASYARAKAT DALAM \\ PENGGUNAAN AMOXICILLIN UNTUK PENGOBATAN SENDIRI DI WILAYAH KELURAHAN LOLU SELATAN KECAMATAN \\ PALU SELATAN
}

\author{
Firdawati Amir Parumpu \\ Akademi Farmasi Tadulako Farma, Palu \\ Email : firdaamirparumpu@gmail.com
}

\begin{abstract}
This study was aimed to determine the Society's Levels of Knowledge and Compliance in Using Amoxicillin to Self-Medicate in South Lolu Urban Village, South Palu Sub-District. The basis of this study was descriptive survey and descriptive analytical approach aided by frequency table and percentage. Data and material collection was performed using observation, interview accompanied by questionnaire or list of question. The samples in this study were 75 adults in South Lolu Urban Village, South Palu Sub-District who were considered to know the research object, representing a population of 772 households. Based on the research result, it was determined that quite a lot of people in South Lolu Urban Village, South Palu SubDistrict didn't have any knowledge on Amoxicillin, influencing people's level of compliance to rules of taking amoxicillin. It's also due to other reasons, such as trying based on people's recommendation, recovery after self-medicating, and unwillingness to take medicine for a long time. Therefore, socialization was required to support the knowledge of the people of South Lolu Urban Village, South Palu SubDistrict to reduce resistance.
\end{abstract}

Keywords : Amoxicillin, knowledge, compliance, resistance.

\section{PENDAHULUAN}

Berbagai macam penyakit telah tersebar di seluruh dunia dengan hampir sebagiannya merupakan penyakit akibat infeksi bakteri, virus dan lain-lain, mulai dari penyakit ringan yang dapat diobati sendiri berdasarkan pengalaman medis seseorang sampai dengan penyakit berat yang membutuhkan penanganan langsung dari ahli medis yaitu dokter. Pengobatan sendiri adalah penggunaan obat oleh masyarakat untuk tujuan pengobatan sakit ringan (minor illnesses), tanpa resep atau intervensi dokter. ${ }^{1}$ Pengobatan sendiri dalam hal ini dibatasi hanya untuk obat-obat modern, yaitu obat bebas dan obat bebas terbatas. Keuntungan pengobatan sendiri menggunakan 
Tingkat pengetahuan dan kepatuhan masyarakat dalam penggunaan amoxicillin untuk pengobatan sendiri di wilayah kelurahan lolu selatan kecamatan palu selatan

obat bebas dan obat bebas terbatas antara lain: aman bila digunakan sesuai dengan aturan, efektif untuk menghilangkan keluhan (karena $80 \%$ keluhan sakit bersifat self-limiting), efisiensi biaya, efisiensi waktu, bisa ikut berperan dalam mengambil keputusan terapi, dan meringankan beban pemerintah dalam keterbatasan jumlah tenaga dan sarana kesehatan di masyarakat. ${ }^{2}$

Jenis obat-obatan yang sering digunakan dalam pengobatan sendiri oleh masyarakat adalah antibiotik. Antibiotik adalah zat -zat kimia yang dihasilkan oleh fungi dan bakteri, yang memiliki khasiat yang mematikan atau menghambat pertumbuhan kuman, sedangkan toksisitasnya pada manusia relatif. $^{3}$

Salah satu antibiotik yang sering kita temukan dipasaran secara bebas adalah amoxicillin, amoxicillin adalah antibiotik dengan spektrum luas, digunakan untuk pengobatan seperti yang tertera diatas, yaitu untuk infeksi pada saluran napas, saluran empedu, dan saluran seni, gonorhu, gastroenteris, meningitis dan infeksi karena Salmonella sp., seperti demam tipoid. ${ }^{4}$ Amoxicillin adalah turunan penisilin yang tahan asam tetapi tidak tahan terhadap penisilinase..$^{5}$
Suatu konsekuensi yang tidak terelakkan dari penggunaan antibiotik adalah timbulnya mikroorganisme yang resisten. ${ }^{6}$ Penggunaan antibiotik yang berlebihan dan tidak tepat telah memotori peningkatan dalam pemunculan patogen - patogen yang resisten terhadap berbagai obat. $^{7}$ Kesalahan dalam penggunaan antibiotik serta pengetahuan tentang antibiotik yang tidak tepat dapat memicu resistensi bakteri terhadap antibiotik yang merupakan masalah kesehatan global saat ini.

Berdasarkan hal ini, maka mendorong dilakukan penelitian yang bertujuan untuk melihat tingkat pengetahuan dan pengetahuan masyarakat khususnya di Wilayah Kelurahan Lolu Selatan Kecamatan Palu Selatan Kota Palu Provinsi Sulawesi Tengah terhadap penggunaan obat amoxicillin. Kurangnya informasi jenis penyakit dan jenis obat apa yang cocok digunakan untuk mengobati penyakit tersebut menyebabkan penggunaan jenis dan dosis obat yang salah dalam masyarakat. Penggunaan obat antibiotik menjadi bebas dengan alasan pengalaman dalam penggunaan obat tersebut, selain itu masyarakat yang melakukan pengobatan sendiri cenderung 
Tingkat pengetahuan dan kepatuhan masyarakat dalam penggunaan amoxicillin untuk pengobatan sendiri di wilayah kelurahan lolu selatan kecamatan palu selatan

menggunakan antibiotik lebih singkat dibandingkan dengan masyarakat yang melalui resep dokter. Hal tersebut mungkin disebabkan karena beberapa faktor diantaranya faktor coba-coba, kemampuan ekonomi atau harga obat yang mahal, penyakit yang diderita sudah dirasa sembuh dengan cara pengobatannya sendiri atau karena malas minum obat.

\section{METODE PENELITIAN}

\section{Tempat Dan Waktu Penelitian}

Penelitian ini dilaksanakan pada bulan Agustus Tahun 2010. Penelitian ini mengambil lokasi di Wilayah Kelurahan Lolu Selatan Kecamatan Palu Selatan.

\section{Populasi Dan Sampel}

\section{Populasi}

Populasi pada penelitian ini sesuai dengan tujuan dan permasalahan penelitian yaitu masyarakat dewasa yang bertempat tinggal di wilayah Kelurahan Lolu Selatan Kecamatan Palu Selatan yang berjumlah 3224 KK (Kepala Keluarga).

\section{Sampel}

Pengambilan sampel pada penelitian ini dilakukan secara bertahap (Multistage Sampling), yang dilakukan dalam beberapa tahap, yaitu :

1. Tahap pertama, memilih daerah atau lokasi penelitian yaitu wilayah Kelurahan Lolu Selatan Kecamatan
Palu Selatan dengan metode acak sederhana (simple random sampling).

2. Tahap kedua, Wilayah Kelurahan Lolu Selatan memiliki 11 RW maka dipilih 3 RW dengan metode acak sederhana (simple random sampling), yaitu RW05 (258KK), RW07 (230KK) dan RW09 (284KK) maka ketiga RW tersebut memiliki KK berjumlah $772 \mathrm{KK}$.

3. Tahap ketiga, memilih sampel di setiap RW sebanyak $25 \mathrm{KK}$ yang mewakili masyarakat dewasa di Wilayah Kelurahan Lolu selatan. Pemilihan sampel dilakukan dengan metode acak sederhana (simple random sampling). Jumlah sampel sebanyak $75 \mathrm{KK}$ dianggap telah mewakili jumlah populasi.

\section{Metode Pengumpulan Data}

Proses pengumpulan data dimulai dari observasi mendata jumlah kepala keluarga di wilayah kelurahan lolu selatan kecamatan palu selatan kota palu kemudian menghitung sampel. Selanjutnya dilakukan pengambilan data, dengan cara interview atau wawancara dan pengisian kuesioner atau daftar pertanyaan yang telah disiapkan oleh peneliti.

\section{Analisis Data}

Analisis data yang digunakan dalam penelitian ini yaitu dengan 
Tingkat pengetahuan dan kepatuhan masyarakat dalam penggunaan amoxicillin untuk pengobatan sendiri di wilayah kelurahan lolu selatan kecamatan palu selatan

menggunakan deskriptif kualitatif dengan menggunakan alat bantu berupa tabel frekuensi dan persentase. Adapun rumusnya dapat dilihat sebagai berikut :<smiles>N#[W]O</smiles>

Keterangan :

$\mathrm{P}=$ Persentase

$\mathrm{F}=$ Frekuensi/Jumlah jawaban dari setiap alternatif

$\mathrm{N}$ = Jumlah sampel/responden

\section{HASIL PENELITIAN}

Tabel 1. Persentase tanggapan responden mengobati sendiri penyakit yang diderita

\begin{tabular}{|c|c|c|c|c|}
\hline No. & Kategori & Jumlah Responden & Persentase (\%) & Ket \\
\hline 1 & Sangat sering & 43 & 57,33 & \\
\hline 2 & Sering & 24 & 32 & \\
\hline 3 & Kadang-kadang & 8 & 10,67 & \\
\hline 4 & Tidak pernah sama sekali & 0 & 0 & \\
\hline & Jumlah & 75 & 100 & \\
\hline
\end{tabular}

Sumber : Hasil data primer diolah Tahun 2010

Tabel 2. Persentase tanggapan responden mengetahui obat untuk penyakit ringan yang diderita

\begin{tabular}{|c|c|c|c|c|}
\hline No. & Kategori & Jumlah Responden & Persentase (\%) & Ket \\
\hline 1 & Sangat tahu & 22 & 29,33 & \\
\hline 2 & Tahu & 30 & 40 & \\
\hline 3 & Kurang tahu & 17 & 22,67 & \\
\hline 4 & Tidak tahu sama sekali & 6 & 8 & \\
\hline & Jumlah & 75 & 100 & \\
\hline
\end{tabular}

Sumber : Hasil data primer diolah Tahun 2010

Tabel 3. Persentase tanggapan responden mengetahui obat antibiotika

\begin{tabular}{|c|c|c|c|c|}
\hline No. & Kategori & Jumlah Responden & Persentase(\%) & Ket \\
\hline 1 & Sangat tahu & 10 & 13,33 & \\
\hline 2 & Tahu & 39 & 52 & \\
\hline 3 & Kurang tahu & 18 & 24 & \\
\hline 4 & Tidak tahu sama sekali & 8 & 10,67 & \\
\hline & Jumlah & 75 & 100 & \\
\hline
\end{tabular}

Sumber : Hasil data primer diolah Tahun 2010 
Tingkat pengetahuan dan kepatuhan masyarakat dalam penggunaan amoxicillin untuk pengobatan sendiri di wilayah kelurahan lolu selatan kecamatan palu selatan

Tabel 4. Persentase tanggapan responden mengkonsumsi antibiotika untuk mengobati penyakit ringan yang diderita

\begin{tabular}{|c|c|c|c|c|}
\hline No. & Kategori & Jumlah Responden & Persentase (\%) & Ket \\
\hline 1 & Sangat sering & 16 & 21,33 & \\
\hline 2 & Sering & 29 & 38,67 & \\
\hline 3 & Kadang-kadang & 21 & 28 & \\
\hline 4 & Tidak pernah sama sekali & 9 & 12 & \\
\hline & Jumlah & 75 & 100 & \\
\hline
\end{tabular}

Sumber : Hasil data primer diolah Tahun 2010

Tabel 5. Persentase tanggapan responden mengetahui cara pemakaian amoxicillin

\begin{tabular}{|c|c|c|c|c|}
\hline No. & Kategori & Jumlah Responden & Persentase(\%) & Ket \\
\hline 1 & Sangat tahu & 12 & 16 & \\
\hline 2 & Tahu & 17 & 22,67 & \\
\hline 3 & Kurang tahu & 31 & 41,33 & \\
\hline 4 & Tidak tahu sama sekali & 15 & 20 & \\
\hline & Jumlah & 75 & 100 & \\
\hline
\end{tabular}

Sumber : Hasil data primer diolah Tahun 2010

Tabel 6. Persentase tanggapan responden mematuhi cara pemakaian amoxicillin

\begin{tabular}{|c|c|c|c|c|}
\hline No. & Kategori & Jumlah Responden & Persentase(\%) & Ket \\
\hline 1 & Sangat patuh & 11 & 14,67 & \\
\hline 2 & Patuh & 38 & 50,67 & \\
\hline 3 & Kurang Patuh & 22 & 29,33 & \\
\hline 4 & Tidak patuh sama sekali & 4 & 5,33 & \\
\hline & Jumlah & 75 & 100 & \\
\hline
\end{tabular}

Sumber : Hasil data primer diolah Tahun 2010

Tabel 7. Persentase tanggapan responden mengetahui dampak jika tidak konsisten dalam pemakaian amoxicillin

\begin{tabular}{|c|c|c|c|c|}
\hline No. & Kategori & Jumlah Responden & Persentase(\%) & Ket \\
\hline 1 & Sangat tahu & 3 & 4 & \\
\hline 2 & Tahu & 8 & 10,67 & \\
\hline 3 & Kurang tahu & 43 & 57,33 & \\
\hline 4 & Tidak tahu sama sekali & 21 & 28 & \\
\hline & Jumlah & 75 & 100 & \\
\hline
\end{tabular}

Sumber : Hasil data primer diolah Tahun 2010 
Tingkat pengetahuan dan kepatuhan masyarakat dalam penggunaan amoxicillin untuk pengobatan sendiri di wilayah kelurahan lolu selatan kecamatan palu selatan

Tabel 8. Persentase tanggapan responden penyebab tidak konsisten menggunakan amoxicillin

\begin{tabular}{|c|c|c|c|c|}
\hline No. & Kategori & Jumlah Responden & Persentase(\%) & Ket \\
\hline 1 & $\begin{array}{l}\text { Coba-coba } \\
\text { (Rekomendasi orang) }\end{array}$ & 22 & 29,33 & \\
\hline 2 & $\begin{array}{l}\text { Keadaan ekonomi } \\
\text { (Harga obat) }\end{array}$ & 0 & 0 & \\
\hline 3 & $\begin{array}{l}\text { Sudah sembuhnya penyakit } \\
\text { sesuai dengan cara } \\
\text { pengobatan sendiri }\end{array}$ & 21 & 28 & \\
\hline 4 & $\begin{array}{l}\text { Kemalasan untuk minum obat } \\
\text { dalam jangka waktu yang } \\
\text { lama }\end{array}$ & 32 & 42,67 & \\
\hline & Jumlah & 75 & 100 & \\
\hline
\end{tabular}

Sumber : Hasil data primer diolah Tahun 2010

Tabel 9. Persentase tanggapan responden dimana membeli amoxicillin

\begin{tabular}{|c|c|c|c|c|}
\hline No. & Kategori & Jumlah Responden & Persentase(\%) & Ket \\
\hline 1 & Warung / Kios pedagang kecil & 5 & 6,67 & \\
\hline 2 & Apotek & 47 & 62,67 & \\
\hline 3 & Puskesmas / Dokter Praktek & 23 & 30,67 & \\
\hline 4 & Toko obat & 0 & 0 & \\
\hline & Jumlah & 75 & 100 & \\
\hline
\end{tabular}

Sumber : Hasil data primer diolah Tahun 2010

Tabel 10. Persentase tanggapan responden darimana mendapatkan informasi tentang amoxicillin

\begin{tabular}{|c|c|c|c|c|c|}
\hline No. & \multicolumn{2}{|l|}{ Kategori } & Jumlah Responden & Persentase(\%) & Ket \\
\hline 1 & Dokter & & 15 & 20 & \\
\hline 2 & Pelayanan Apotek & & 36 & 48 & \\
\hline & $\begin{array}{l}\text { (Apoteker dan } \\
\text { apoteker) }\end{array}$ & Asisten & & & \\
\hline 3 & $\begin{array}{l}\text { Media Informasi } \\
\text { (Cetak dan Elektronik) }\end{array}$ & & 4 & 5,33 & \\
\hline 4 & Mulut ke mulut & & 20 & 26,67 & \\
\hline & Jumlah & & 75 & 100 & \\
\hline
\end{tabular}

Sumber : Hasil data primer diolah Tahun 2010

\section{PEMBAHASAN}

Berdasarkan hasil dari tabeltabel tersebut di atas, maka dapat dilihat bahwa responden yang mengobati sendiri penyakit ringan yang dideritanya sebanyak 43 responden atau 57,33\% sangat sering, 24 responden atau $32 \%$ sering, 8 
Tingkat pengetahuan dan kepatuhan masyarakat dalam penggunaan amoxicillin untuk pengobatan sendiri di wilayah kelurahan lolu selatan kecamatan palu selatan

responden atau $10,67 \%$ kadangkadang dan 0 responden atau $0 \%$ tidak pernah sama sekali. Hal tersebut disebabkan karena responden yang mengetahui jenis obat yang cocok untuk penyakitnya sebanyak 22 responden atau $29,33 \%$ sangat tahu, 30 responden atau $40 \%$ tahu, 17 responden atau $22,67 \%$ kurang tahu dan 6 responden atau $8 \%$ tidak tahu sama sekali.

Setelah melihat hasil dari data responden mengetahui jenis obat yang cocok untuk penyakitnya di atas, maka selanjutnya tanggapan responden yang mengetahui obat antibiotika sebanyak 10 responden atau $13,33 \%$ sangat tahu, 39 responden atau $52 \%$ tahu, 18 responden atau 24\% kurang tahu dan 8 responden atau $10,67 \%$ tidak tahu sama sekali. Tingkat pengetahuan masyarakat tentang antibiotika berpengaruh terhadap responden yang mengkonsumsi antibiotika Amoxicillin untuk mengobati penyakit ringan yang dideritanya sebanyak 16 responden atau $21,33 \%$ sangat sering, 29 responden atau $38,67 \%$ sering, 21 responden atau $28 \%$ kadang-kadang dan 9 responden atau $12 \%$ tidak pernah sama sekali.

Tanggapan responden yang mengetahui cara pemakaian Amoxycillin sebanyak 12 responden atau $16 \%$ sangat tahu, 17 responden atau 17 responden atau $22,67 \%$ tahu, 31 responden atau $41,33 \%$ kurang tahu dan 15 responden atau $20 \%$ tidak tahu sama sekali. Setelah mengetahui cara pemakaian Amoxycillin maka selanjutnya tanggapan responden mematuhi cara pemakaian amoxicillin sebanyak 11 responden atau $14,67 \%$ sangat patuh, 38 responden atau $50,67 \%$ patuh, 22 responden atau $29,33 \%$ kurang patuh dan 4 responden atau $5,33 \%$ tidak patuh sama sekali.

Tingkat kepatuhan responden dalam mengkonsumsi Amoxicillin dipengaruhi oleh tanggapan responden mengetahui dampak jika tidak mengkonsumsi Amoxicillin sesuai aturan sebanyak 3 responden atau $4 \%$ sangat tahu, 8 responden atau 10,67\% tahu, 43 responden atau $57,33 \%$ kurang tahu, 21 responden atau $28 \%$ tidak tahu sama sekali. Selain itu, alasan penyebab responden tidak konsisten dalam mengkonsumsi Amoxicillin sebanyak 22 responden atau $29,33 \%$ karena coba-coba (rekomendasi orang), 0 responden atau $0 \%$ karena keadaan ekonomi atau harga obat yang mahal, 21 responden atau $28 \%$ karena sudah dirasa sembuh penyakit dengan cara pengobatan sendiri dan 32 responden atau $42,67 \%$ karena kemalasan 
Tingkat pengetahuan dan kepatuhan masyarakat dalam penggunaan amoxicillin untuk pengobatan sendiri di wilayah kelurahan lolu selatan kecamatan palu selatan

minum obat dalam jangka waktu yang lama. Tanggapan responden dimana mendapatkan Amoxicillin sebanyak 5 responden atau $6,67 \%$ di warung atau kios pedagang kecil, 47 responden atau $62,67 \%$ di apotek, 23 responden atau $30,67 \%$ di puskesmas atau dokter praktek dan 0 responden atau $0 \%$ di toko obat. Hal tersebut berpengaruh terhadap informasi yang diterima oleh responden tentang amoxicillin yang dikonsumsinya sebanyak 15 responden atau $20 \%$ dari dokter, 36 responden atau $48 \%$ dari pelayanan apotek (apoteker dan asisten apoteker), 4 responden atau 5,33\% dari media informasi (cetak atau elektronik) dan 20 responden atau $26,67 \%$ dari mulut ke mulut.

Dengan melihat hasil dari datadata di atas, maka dapat diketahui bahwa tingkat pengetahuan responden terhadap Amoxicillin dapat mempengaruhi tingkat kepatuhan responden dalam mengkonsumsi Amoxicillin untuk pengobatan sendiri. Masih banyak responden yang tidak mengetahui apa itu Amoxicillin beserta cara penggunaannya maka banyak pula yang tidak patuh dalam mengkonsumsinya dengan dilatari berbagai macam alasan, diantaranya karena coba-coba (rekomendasi orang), sudah dirasa sembuh penyakit dengan cara pengobatan sendiri dan kemalasan minum obat dalam jangka waktu yang lama. Akan tetapi, jika masyarakat mengetahui tentang Amoxicillin maka tingkat kepatuhan masyarakat akan meningkat. Faktor harga obat yang mahal tidak mempengaruhi masyarakat Wilayah Kelurahan Lolu Selatan Kecamatan Palu Selatan tidak patuh dalam menggunakan Amoxicillin. Hal ini sangat disayangkan, mengingat bahaya atau dampak yang akan diterima Masyarakat apabila salah menggunakan Amoxicillin yaitu resistensi. Oleh sebab itu, sangat diperlukan upaya petugas kesehatan di Wilayah Kelurahan Lolu Selatan Kecamatan Palu Selatan untuk mensosialisasikan Amoxicillin kepada Masyarakat sehingga dapat menekan terjadinya resistensi karena antibiotika.

Dengan melihat hasil di atas maka dapat diketahui bahwa masyarakat di wilayah Kelurahan Lolu Selatan Kecamatan Palu Selatan tidak memiliki tingkat pengetahuan dan kepatuhan dalam penggunaan Amoxicillin untuk pengobatan sendiri.

\section{KESIMPULAN}

1. Masih banyak masyarakat Kelurahan Lolu Selatan Kecamatan Palu Selatan yang mengobati sendiri penyakit ringan yang 
Tingkat pengetahuan dan kepatuhan masyarakat dalam penggunaan amoxicillin untuk pengobatan sendiri di wilayah kelurahan lolu selatan kecamatan palu selatan

dideritanya dengan pengetahuan yang dimilikinya tentang jenis obat yang cocok dengan jenis penyakitnya salah satunya yaitu penggunaan antibiotika Amoxicillin yang dapat berakibat resistensi apabila diminum dengan cara yang salah atau tidak patuh dengan aturan pemakaian Amoxicillin.

2. Ada beberapa alasan mengapa masyarakat Kelurahan Lolu Selatan Kecamatan Palu Selatan tidak konsisten atau tidak patuh dalam mengkonsumsi Amoxicillin diantaranya karena alasan cobacoba (rekomendasi orang), sudah dirasa sembuh penyakit dengan cara pengobatannya sendiri dan kemalasan minum obat dalam jangka waktu yang lama. Sedangkan faktor harga obat yang mahal tidak mempengaruhi masyarakat Wilayah Kelurahan Lolu Selatan Kecamatan Palu Selatan tidak patuh dalam menggunakan Amoxicillin.

\section{DAFTAR PUSTAKA}

1. Shankar PR, Partha P, Shenoy N. Self-medication and non-doctor prescription practices in Pokhara valley, Western Nepal : a questionnaire-based study, BMC Family Practice, (Online), 3 (17), 2002. (http://biomedcentral.org, diakses 22 Mei 2010.

2. Holt GA, Edwin LH. The pros and cons of self-medication. Journals of Pharmaceutical Technology, Pp. 213-218. September/October, 1986.

3. Tjay TH, Kirana Raharja. Obat-Obat Penting. Ed.V. Jakarta: PT. Elex Media Komputindo, 2002.

4. Olson J. Belajar Mudah Farmakologi. Jakarta: EGC Penerbit Buku Kedokteran, 2008.

5. Siswandono. Kimia Medicinal. Surabaya: Airlangga University Press, 2000.

6. Simarmata M. Masalah Terkait Obat (Drug Related Problem). Intervensi apoteker. Jakarta: FMIPA Universitas Indonesia, 2010.

7. Katzung BG. Farmakologi Dasar dan Klinik Buku 3 Edisi 8. Penerjemah dan editor: Bagian Farmakologi FK UNAIR. Surabaya: Penerbit Salemba Medika, 2004 